\title{
Acrobat Ant, Crematogaster ashmeadi Emery (Insecta: Hymenoptera: Formicidae: Myrmicinae) ${ }^{1}$
}

Emily V. Saarinen²

\section{Introduction}

The ant Crematogaster ashmeadi (Emery) is commonly known as an acrobat ant. There are perhaps 10 species of Crematogaster in Florida, and C. ashmeadi is commonly found throughout the state (Deyrup, personal communication). Members of this genus are referred to as acrobat ants because of the flexible way that a worker holds its abdomen (gaster) up over the rest of its body.

\section{Distribution}

Acrobat ants are commonly found throughout Florida and the Southeastern United States (Tschinkel 2002). They are considered native to Florida and are found in most counties (Ferster et al. 2000). They are even recorded from small, mangrove islands in the Florida Keys (Hölldobler and Wilson 1990). Acrobat ants have been recorded as pests in Collier, Hillsborough, Palm Beach, Pinellas, and Polk Counties (Klotz et al. 1995).

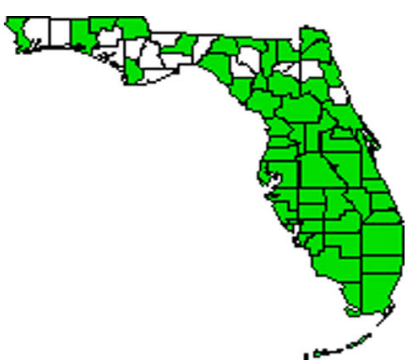

Figure 1. Florida distribution. Credits: Emily V. Heffernan, University of Florida

\section{Description}

Acrobat ants are small to medium sized ants, generally 2.6 to $3.2 \mathrm{~mm}$ long. They have very shiny bodies that are variable in color from light red to brown or black. An acrobat ant's most distinguishing characteristic is its heart-shaped gaster that is held up over its thorax when disturbed.

Crematogaster ashmeadi has a two-segmented petiole, with the postpetiolar attachment at the dorsal surface of the gaster. The gaster is pointed and equipped with a sting that may or may not be everted (Ferster et al. 2000). There is a pair of short spines on the propodeum, and a few hairs on the head or mesosoma. It is difficult to identify ants to species in

1. This document is EENY-333, one of a series of Featured Creatures from the Entomology and Nematology Department, Florida Cooperative Extension Service, Institute of Food and Agricultural Sciences, University of Florida. Published: August 2004. This document is also available on Featured Creatures Website at http://creatures.ifas.ufl.edu. Please visit the EDIS Website at http://edis.ifas.ufl.edu. 2. Emily V. Saarinen, Department of Entomology and Nematology, University of Florida, Gainesville.

The Institute of Food and Agricultural Sciences (IFAS) is an Equal Opportunity Institution authorized to provide research, educational information and other services only to individuals and institutions that function with non-discrimination with respect to race, creed, color, religion, age, disability, sex, sexual orientation, marital status, national origin, political opinions or affiliations. U.S. Department of Agriculture, Cooperative Extension Service, University of Florida, IFAS, Florida A. \& M. University Cooperative Extension Program, and Boards of County Commissioners Cooperating. Larry Arrington, Dean 
the genus Crematogaster, but a new taxonomic key for Florida species is forthcoming (Deyrup, personal communication). C. ashmeadi may be distinguished from other species by its shiny pronotal sides and generally dark color (in live specimens).

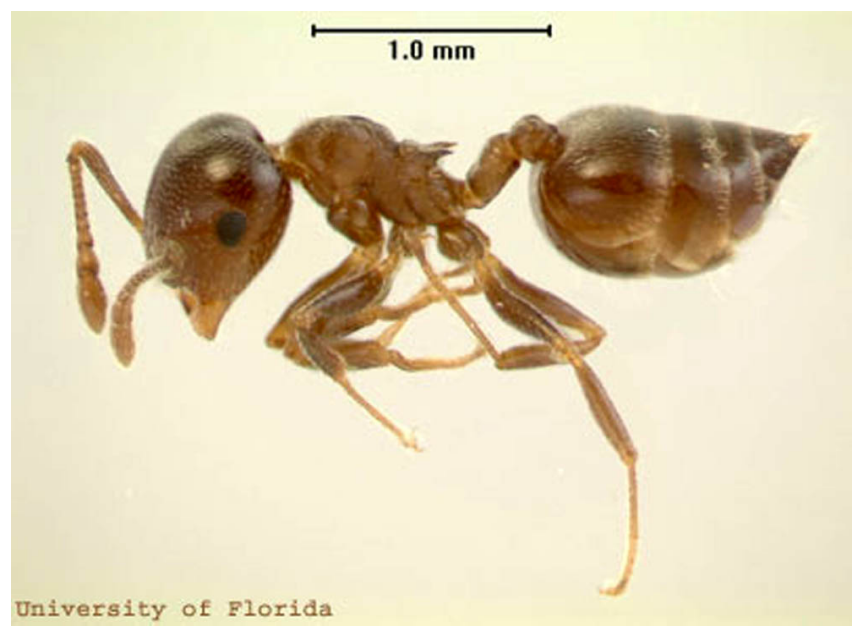

Figure 2. Worker acrobat ant, Crematogaster ashmeadi Emery. Credits: Photograph by: Emily V. Heffernan, University of Florida

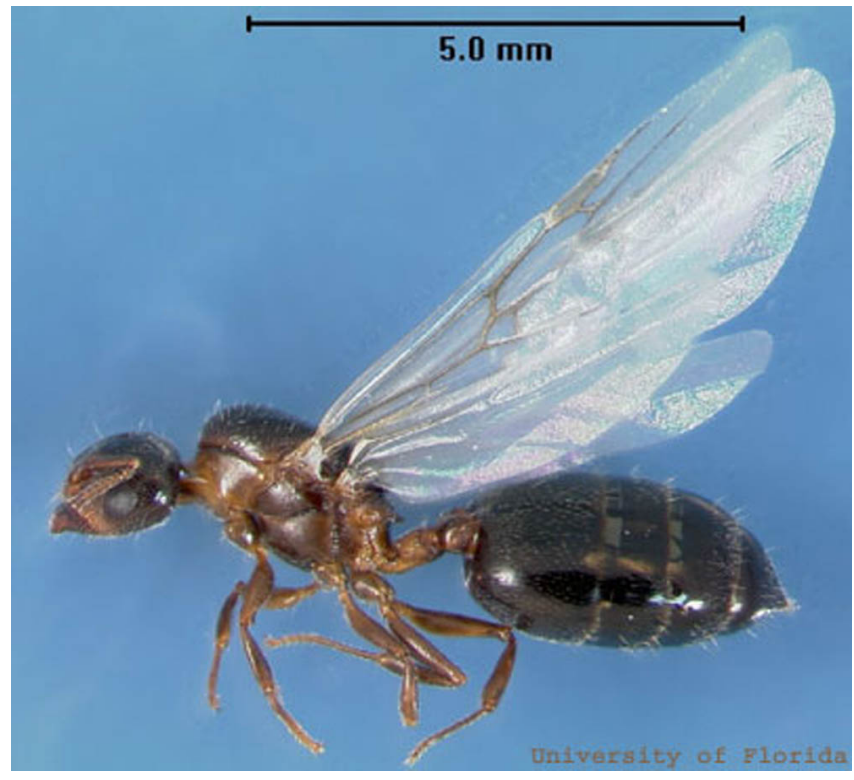

Figure 3. Queen acrobat ant, Crematogaster ashmeadi Emery. Credits: Photograph by: Emily V. Heffernan, University of Florida

\section{Biology and Behavior}

Crematogaster ashmeadi are arboreal ants, nesting in trees and rotten wood. Acrobat ants are the most dominant arboreal ant species in north Florida coastal plain pine forests, comprising $80-90 \%$ of the ants in that forest ecosystem (Tschinkel 2002). The abundance of these ants makes them major ecological factors in these long-leaf pine forests (Tschinkel and Hess 1999). As such, they are the most important source of food for the endangered red-cockaded woodpecker, Picoides borealis, and therefore warrant further research (Tschinkel 2002).

A colony of acrobat ants usually exists in each tree of such coastal plain pine forests, inhabiting the excavated chambers of cossid moth larvae and bark beetles. Acrobat ants are extremely territorial and only one colony exists in each tree, although a large colony may spread to up to three pine trees if trees are in close proximity to each other. Acrobat ants do not damage trees themselves, but rather move into spaces and chambers hollowed out and abandoned by other insects (Tschinkel 2002). Founding queens of Crematogaster ashmeadi search for abandoned galleries of wood boring beetles in the dead branches of longleaf pine saplings. Queens use these galleries as founding chambers to begin new colonies, and only one queen is found per nest (Hahn and Tschinkel 1997). Queens produce minim workers that rear brood and begin foraging. The queen then lays larger monomorphic workers and eventually moves, along with brood, to ex-termite galleries at or below ground level (Tschinkel 2002). Larvae are fed only with the food regurgitations from workers (Hölldobler and Wilson 1990). Colonies contain one queen, but multiple nest sites may occur. Communication and coordination of colony tasks must be highly coordinated as the colony is spread throughout the height of the pine tree, with the queen located at the very bottom of the tree (Tschinkel 2002).

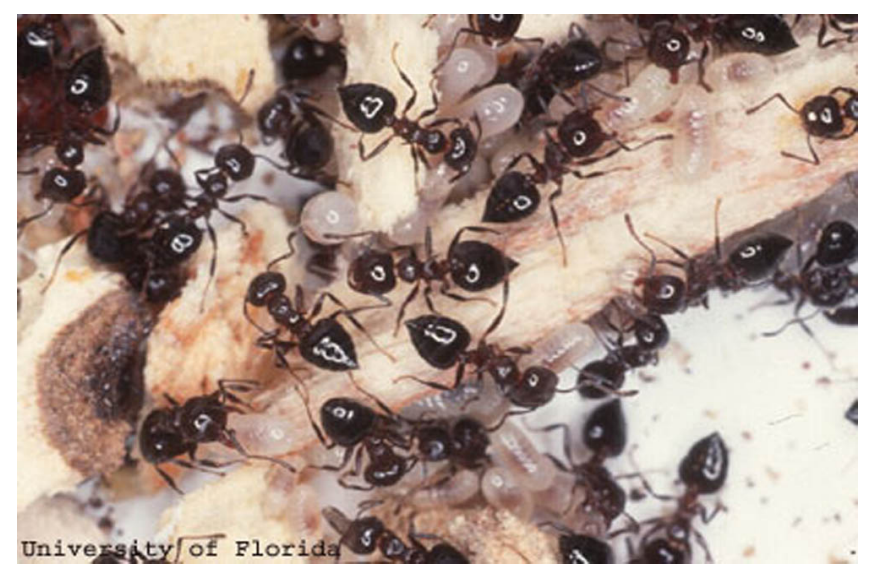

Figure 4. Workers and brood of the acrobat ant, Crematogaster ashmeadi Emery. Credits: Photograph by: J.L. Castner, University of Florida 
Workers are general scavengers and predators, foraging the length of the 30 to $40 \mathrm{~m}$ trees for living and dead insects (Tschinkel 2002). Workers are also often observed tending sap sucking insects (Ferster et al. 2000). Crematogaster sp. ants secrete trailing pheromone from the tibia that allows them to follow trails up and down the tree trunk as connecting routes to good food sources (Hölldobler and Wilson 1990).

Acrobat ants do not nest in sound wood, but are found in damp or rotting wood (Swoboda and Miller 2003). The nesting capabilities of acrobat ants often depends on the activities of cavity- excavating insects such as caterpillars of the cossid moth, termites, and buprestid and cerambicid beetles (Tschinkel 2002).

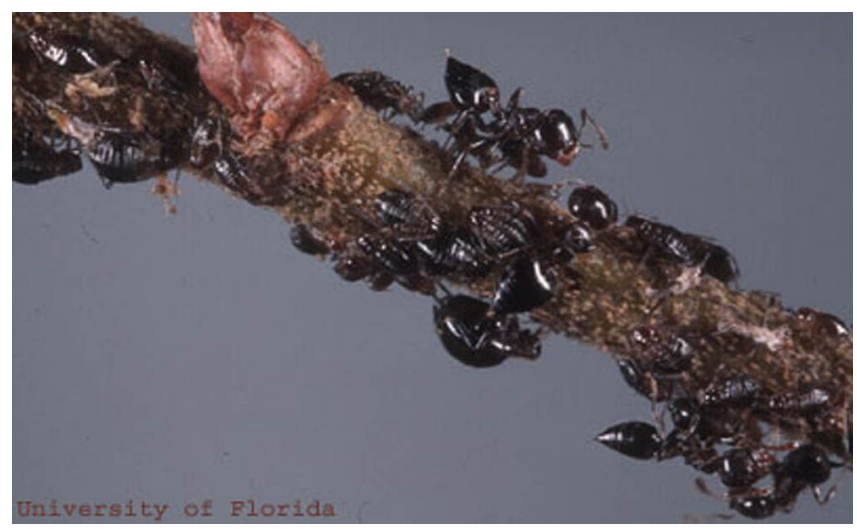

Figure 5. Workers of the acrobat ant, Crematogaster ashmeadi Emery, tending aphids. Credits: Photograph by: L.J. Buss, University of Florida

\section{Pest Status}

When compared with other pestiferous ant species, acrobat ants are usually of minimal nuisance to people. Homeowners may complain that these ants are in the yard and foraging outside the home. They may nest in trees on the homeowner's property or in decayed wood around the home in places like porches and eaves (Ferster et al. 2000). They are uncommon indoors, but may be observed foraging for sweets or protein inside. When they are found nesting in the home, they infest damp or rotting wood often around windows and drain spouts. They may also be found in damp foam board or insulation. These ants do minimal damage to wood, but their frass may be of concern to homeowners. Their presence also indicates the presence of wet and/or decaying wood (Swoboda and Miller 2003).
A 1995 survey by Klotz et al. showed that of the genus Crematogaster, only C. ashmeadi appeared as a pest ant in Florida. It was encountered nine times in the extensive survey, and six of these occurrences were indoors. Several occurrences located nests within buildings. Because of their limited occurrence in this survey, C. ashmeadi are referred to as occasional pest ants (Klotz et al. 1995).

\section{Management}

Control of acrobat ants can usually be done by reducing access to the home or other structures (Ferster et al. 2000). Management can be accomplished by sealing exterior cracks through which workers enter. Removing branches or rotten $\operatorname{logs}$ and stumps will usually remove the nest site and the problem. Cutting away branches and tree material that touches the home will further remove the ant's access to the home.

Acrobat ant colonies that live in the walls may be treated by eliminating damp wood and other sources of moisture. If problems persist, insecticidal spray or dust may be injected into infested wall voids (Swoboda and Miller 2003).

For more management information see Insect Management Guide for Ants (http://edis.ifas.ufl.edu/IG080).

\section{Selected References}

Deyrup M. (2003). An updated list of Florida ants (Hymenoptera: Formicidae). Florida Entomologist 86:43-48. http://www.fcla.edu/FlaEnt/ fe85p658.pdf (15 July 2004).

Ferster B, Deyrup M, Scheffrahn RH, Cabrera BJ. (2000). The pest ants of Florida. http://flrec. ifas.ufl.edu/entomo/ants/Pest $\% 20$ Ants $\% 20 \mathrm{of} \% 20 \mathrm{FL} /$ index.htm (15 July 2004).

Hölldobler B, Wilson EO. (1990). The Ants. Belknap Press of Harvard University Press. Cambridge, MA. 732 pp.

Hahn DA, Tschinkel WR. (1997). Settlement and distribution of colony-founding queens of the arboreal ant, Crematogaster ashmeadi, in a long-leaf pine forest. Insectes Sociaux 44:323-336. 
Klotz JH, Mangold JR, Vail KM, Davis, Jr. LR, and Patterson RS. (1995). A survey of the urban pest ants (Hymenoptera: Formicidae) of Peninsular Florida. Florida Entomologist 78:109-118.

Swoboda L, Miller DN. (2003). Acrobat ant. Virginia Cooperative Extension Knowledge for the Commonwealth. http://www.ext.vt.edu/pubs/ entomology/444-287/444-287.html (15July 2004).

Tschinkel WR. (2002). The natural history of the arboreal ant, Crematogaster ashmeadi. Journal of Insect Science 2:1-15. http://insectscience.org/2.12 (15 July 2004).

Tschinkel WR, Hess CA. (1999). Arboreal ant community of a pine forest in northern Florida. Annals of the Entomological Society of America 92:63-76. 